\title{
Investigating the Socio-Economic Impacts of Climate- Induced Drought Risks on Resettled Women Farmers in Mashonaland Central Province, Zimbabwe
}

\author{
Moddie Nyahwo ${ }^{1}$, Bernard Moeketsi Hlalele ${ }^{2, *}$ and Alice Ncube 1,* \\ 1 Disaster Management Training and Education Centre for Africa (DiMTEC), Faculty of Natural and \\ Agricultural sciences, University of the Free State, Bloemfontein 9301, South Africa; \\ moddienyahwo@gmail.com \\ 2 Department of Business Support Studies, Faculty of Management Sciences, Central University of \\ Technology, Bloemfontein 9300, South Africa \\ * Correspondence: hlalele.moeketsi@gmail.com (B.M.H.); NcubeA@ufs.ac.za (A.N.); Tel.: +27-736985797 \\ (B.M.H.)
}

\begin{abstract}
The resettlement programme in the post independent Zimbabwe was conducted to address socio-economic imbalances between the white farmers and the majority black population. The study focused on women because of gender inequalities and the historical background of patriarchal society. The aim of this study is to investigate the social and economic impacts of drought on the resettled women farmers. The data base of resettled women is not clear but based on the specific demographics such as similar type of crops and livestock, the sample of resettled women was taken. Convergence parallel mixed method design was applied. A multi sampling technique was used for purposively selecting three out of seven districts in Mashonaland Central province and stratified random sampling, and simple random sampling were also applied. Qualitative data was analysed by extracting themes and quantitative data was analysed using reliability test analysis and descriptive statistics per latent variable. The results showed that the nutrition of the women famers and their families was diminished, some of the children droped out of school because the women farmers were not able to pay school fees. The study recommended that the government and other organisations should offer financial assistance and conduct more drought awareness campaigns.
\end{abstract}

Keywords: climate change; drought; resettled farmers; women; Mashonaland Central; Zimbabwe

PACS: J0101

\section{Introduction}

Drought is defined according to different standards and it is classified into hydrological, metrological, agriculture and socio-ecological drought (Chae, Lee and Um, 2012) [1] (p2). Drought has caused devasted impacts to farmers across the world and women farmers are at a greater risk as compared to their male counterparts. Women farmers in Mashonaland Central, Zimbabwe are facing a series of challenges due to the impacts of drought that are attributed to climate change, hence feminisation of drought and agricultural activities in Zimbabwe. It is also evident that climate change is not gender neutral but gender sensitive as it affects women different from men. Hence the aim of this study is to investigate the social and economic impacts of drought on the resettled women farmers.

\subsection{Overview of Zimbabwe's post-independence land reform processes}

Zimbabwe gained independence in 1980 but ownership of most of the most productive land was owned by approximately 6,034 white commercial farmers (Kudejira, 2014) [2] (p7). Most of the land possessed by white farmers was in the high agro-ecological regions I, II and III (Nyaya and Mazuru, 
2010) [3] (pp164- 177). Black farmers were settled in the low potential regions with erratic rainfall and poor soils. In order to address the socio-economic imbalances between the white farmers and the majority black population, the resettlement programme was introduced after the country obtained independent.

The post-independence resettlement in Zimbabwe was charactered by three distinctive phases. The first phase was the Lancaster House (willing buyer willing seller) which occurred during 19801990, the second phase was the compulsory acquisition with fair compensation (1990-2000) and the last phase was Fast Track Land Reform Programme (FTLRP), which occurred around the year 20002002 and beyond (Chilunjika and Uwizeyimana, 2015) [4] (pp130- 144). As a result of heightened pressure for land by the landless nationals in the face of inadequate financial resources and insufficient institutional capacities in government, the FTLRP was adopted to speed up the process (Chilunjika and Uwizeyimana, 2015) [4] (pp130- 144). The FTLRP at the initial phase was characterised by land invasions (Sadomba, 2008) [5] (p99), however, most of black farmer were allocated land by the government. There were two models for resettlement under the Fast Track Land Reform Programme (FTLRP), namely A1 scheme and A2 scheme. Women farmers in Mashonaland Central province benefited from the land reform program, however, they were faced with a bigger challenge posed by climate changed induced drought.

\subsection{Theoretical and conceptual background}

Drought has destructive consequences and affects peoples' livelihoods. There are so many countries around the globe that have experienced the negative impacts of drought. Drought has negatively affected livestock production and agriculture in Brazil. According to Cunningham, Cunha, Brito, Marengo and Coutinho (2017) [6] (pp. 361-375)., the 2013 to 2014 drought in Brazil led to economic losses that added up to US\$1.6 billion worth of crops. A great concern on the African continent is the number of drought events experienced in most African countries. The Southern African region is one of the high-risk drought prone areas, the region has been experiencing severe droughts and this can be attributed to sociological and metrological factors (Emergency Response Coordination Centre, 2019) [7] (p1). In Zimbabwe, the 2018 to 2019 drought affected at least more than two million people who faced starvation, after a severe drought affected food harvests (Chingono and Adebayo, 2019) [8]. There were some reports that about 5.5 million people in the rural areas of Zimbabwe were affected by drought during the peak of the hunger season and approximately 2.6 million children needed humanitarian assistance (UNICEF, 2019) [9]. Mashonaland Central is one of the provinces in Zimbabwe that has been experiencing drought and is likely to experience more droughts because of the effects of climate change that the country is exposed to.

\subsection{The patterns and trends of climate change}

Many scientists are attributing drought to the effect of climate change and other effects include a rise in the average temperatures and variations in rainfall (Alam, Bhatia and Mawby, 2015) [10] (14). Climate change has been causing global drought risk for more than a century. To confirm that climate change has a huge influence in African countries, there have been a raise in temperature over Africa in the last five decade as compared to the global rate (Engelbrecht at el, 2015) [11] (p2). In various subtropical and mid-latitude dry regions, the mean precipitation is likely to decrease, whereas in different mid-latitude wet areas, the mean precipitation is anticipated to increase (Coast Adapt, 2017) [12]. The IPCC report indicated that intense precipitation in most areas, and the probability of drought and precipitation deficits in numerous regions (IPCC, 2018) [13] (p9). Zimbabwe is experiencing the impacts of climate change and this has led to many changes. Some of the changes include increasing temperatures and a decrease in precipitation in most parts of the country. An increase of $2^{\circ} \mathrm{C}$, while the number of cold days has reduced and hotter days have increased is been experienced (Brown, Chanakira, Chatiza, Dhliwayo, Dodman, Masiiwa, Muchadenyika, Mugabe and Zvigadza, 2012) [14] (p3). 


\subsection{Women and climate change}

Climate change has posed a major risk to people's security, predominantly for women since they represent 70 percent of the poor people in the world (Brown at el, 2012) [14] (p12). Adding to the inequitable consequences of disasters on women's morbidity and mortality, climate change is anticipated to endanger women's livelihoods by lessening economic prospects, specifically for households that are headed by women (Tanyanyiwa and Mufunda, 2020) [15]. The risks women farmers encounter as a result of climate change lead to income and food insecurity and restrained decision-making capabilities result in undesirable impacts on the health of women. For some of the women who have endured the impacts of droughts and other climate change related events, the ability to adapt to the new conditions might be very challenging. Women farmers generally do not have legal assets including rights to property, this leaves them with insufficient resources to reestablish their lives (FAO, 2018) [16] (pp1-80). The scarcity of livelihood means women preside over households lacking the social stature or the material resources.

\subsection{Study area}

The geographical area of the research study was Mashonaland Central province. The province covers the northern part of Zimbabwe and stretches as far as the Zambezi valley and to the border of Mozambique in the north-east (Environmental Management Agency, 2014) [17]. Mashonaland Central province has an area of $28.347 \mathrm{~km}^{2}$ and a population of 1.152520 , representing approximately 8.5\% of the total population in Zimbabwe (Zimbabwe National Statistics Agency, 2012) [18] (17). Agriculture is essential for the social and economic development of the province. The province lies in the agro-ecological region II, this region is known for intensive livestock and crop production (Musemwa, 2011) [18]. Rainfall in this province is moderately high (700 to $1050 \mathrm{~mm}$ ) and is more confined to summer (Zimfact, 2018) [20]. There are other small sections of the province that come under regions III and IV which are fit for semi-intensive farming and semi-extensive farming, respectively (Ministry of Lands Agriculture, Water, Climate and Rural resettlement. 2017) [21]. The study area was chosen because the province had a high number of women farmers who were resettled during the (FTLRP) and the province is prone to drought.

\section{Results}

To acquire the level of climate change- induced drought impact in Mashonaland Central province different questions relating to their experiences were discussed. Table 1 below illustrates how drought influenced resettled women farmers. A reliability test was conducted using the Cronbach's Alpha, the results of the test were 0.754 , this proved that the data was reliable.

Table 1. Hazards and stresses affecting resettled women.

\begin{tabular}{cccc}
\hline & $\begin{array}{c}\text { Knowledge of climate change/ drought } \\
\text { impacts }\end{array}$ & $\begin{array}{c}\text { Loss of } \\
\text { livestock }\end{array}$ & $\begin{array}{c}\text { Loss of } \\
\text { crops }\end{array}$ \\
\hline Valid & 267 & 267 & 267 \\
\hline Missing & 0 & 0 & 0 \\
\hline Median & 2.000 & 2.000 & 1.000 \\
\hline Mode & 2.000 & 2.000 & 1.000 \\
\hline Standard Deviation & 0.487 & 0.499 & 0.307 \\
\hline Shapiro-Wilk & 0.637 & 0.643 & 0.351 \\
\hline $\begin{array}{c}\text { P-value of Shapiro- } \\
\text { Wilk }\end{array}$ & $<.001$ & $<.001$ & $<.001$ \\
\hline Minimum & 1.000 & 1.000 & 1.000 \\
\hline Maximum & 3.000 & 3.000 & 5.000 \\
\hline
\end{tabular}

Source: (Survey, 2019). 
Women farmers in Mashonaland Central have recorded financial loss because of drought. Drought directly and indirectly affects women farmers. The losses that these women farmers have recorded losses ranges from crop failure, loss of animals, lack of crop insurance and lack of labour.

Table 3. Causes of financial loses.

\begin{tabular}{cc}
\hline Area affected & Losses recoded \\
\hline Crop failure & $30 \%$ \\
\hline Loss of animal & $23 \%$ \\
\hline Loss of crops due to lack of insurance & $19 \%$ \\
\hline Inadequate relief funds & $20 \%$ \\
\hline Lack of labour & $8 \%$ \\
\hline
\end{tabular}

Source: (Survey, 2019).

\section{Discussion}

Most of the respondents do not have knowledge of climate change and drought impacts. Frankenberg, Sikoki, Sumantri, Suriastini, Thomas (2013) [22] (pp1-13) indicated that education plays an important role when it comes to managing a disaster. Some of the respondents indicated that they did not attend school, and some went as far as primary school therefore, it was difficult for them to be familiar with the impacts of climate change. From the data presented on Table 1, most of the respondents did not lose their livestock due to drought. The reason being few resettled women indicated that they were practising pastoral farming. However, the farmers that specified that they lost their livestock during drought also revealed that they lost the livestock through selling. The agriculture experts interviewed indicated that some women farmers are selling their livestock to compensate for the lack of income due to bad harvests. The results are in line with the findings documented by Tau (2015) [23]. The researcher revealed that selling livestock during drought is a common practice, some farmers sell their livestock to buy food.

Most of the respondents said they have lost their crops due to drought. From the observations conducted, most farmers in the province were growing maize, tobacco, soya beans and some were involved in market gardening. Agriculture experts and local leaders indicated that there is inadequate food in the province, women farmers are losing their crops and livestock, so women are finding it difficult to feed their families. They also indicated that in worst cases some women are resorting to immoral activities such as prostitution, just to find a way to survive. Loss of crops has a serious impact on the province and the country as well. The resettled women indicated that they are struggling to feed their families due to lost income since most of the farmers sell their crops, the nutrition of the women famers and their families has diminished. There is also evidence that in Zimbabwe about 5.5 million people in the rural areas of Zimbabwe were affected by drought during the peak of the hunger season and almost 2.6 million children needed humanitarian assistance (UNICEF, 2019) [9]. The literature shows that resettled women experienced the same impacts of drought that other regions have experienced. Loss of crops has a negative impact on the food security of the country and the economy since Zimbabwe is an agriculture-based economy.

\section{Financial losses}

Women farmers who participated in the study were asked to indicate the reason behind their financial losses due to drought (table 2). The majority (30 percent) of the women farmers said that they encountered some financial losses when their crops failed because of drought. The farmers were hoping to sell their crops after harvest but when drought occurred, these women farmers were left with few and some did not have any crop to sell. The women farmers expressed that they were not able to buy inputs for the next farming seasons and were not able to pay back loans. Twenty-three percent of the women farmers indicated that they experienced some financial losses because they had lost their livestock. These women recorded some financial losses because some of their livestock died and they sold the remaining livestock for a very low amount. As a result of the economic constrains 
experienced the resettled women, some women farmers revealed that the children have dropped out of school because the women farmers were not able to pay school fees.

Nineteen percent of the respondents indicated that they experienced some financial losses because they did not have insurance. This insurance would assist farmers against weather related challenges such as drought. There were $20 \%$ of the respondents who made financial losses due to inadequate relief funds. These women emphasised that they made financial losses because they did not get enough seeds and fertilisers from the government. FAO (2019) [24] (pp24) reported that there were losses recorded in the developing world agriculture during 2005 and 2015, the losses countered for $\$ 29$ billion. Most of the respondents that indicated that they recorded losses because of labour were A2 farmers. Labour is normally needed in A2 farms because the farms are bigger in size.

\section{Materials and Methods}

The study is based on a convergence parallel mixed method design. The target population consisted of women involved in farming and obtained their land through the FTLRP. Given the mixed nature of the research, a multi sampling technique was used. The first part of the sampling comprised of purposively sampling resettled women in Mashonaland Central province. The strata used in the study was 267 resettled women farmers. The actual sample per district was Bindura 120, Shamva 67, and Muzarabini 80 respondents. The researcher conducted interviews with 5 of the resettled farmers who further elaborated about issues that they were experiencing. Face to face interviews were conducted with extension officers, agronomist, agriculture manager and the local leaders. A random sampling method was utilised to select the participants who were interviewed. During data collection, the researcher observed all the relevant information. The data collected from the qualitative method was analysed through the extraction of themes. To analyse quantitative data, the exploration of demographics using tables (MS excel), reliability test analysis (using SPSS V25 IBM), Cronbach's alpha coefficient and descriptive statistics per latent variable, were used.

\section{Conclusions}

The resettled women famers lost their crops and they have struggled to feed their families and they find it difficult to get an income since most of the farmers survive through selling their crops. Some of the children droped out of school because the women farmers were not able to pay school fees. The women farmers were not able to buy inputs for the next farming seasons and were not able to pay back loans. The study recommended that the government and other organisations should offer financial assistance, conduct more drought awareness campaigns and encourage women farmers to have alternatives sources of livelihood.

\section{References}

1. Chae, H.M., Lee, S \&Um, G.J. 2012. The effects of drought on forest and forecast of drought by climate change in Gangwon region. Journal of Forest Science Climate Change Research, Vol. 28, No. 2, pp. 97-105. ISSN 2287-2396. Institute of Korea. Republic of Korea,

2. Kudejira, D. 2014. An integrated approach towards moderating the effects of climate change on agriculture: A policy perspective for Zimbabwe. Early Career Fellowship Programme.

3. Nyaya, T. \& Mazuru, N. 2010. Land reform process and property rights in Zimbabwe: constraints and future prospects. Journal of Sustainable Development in Africa, Vol. 12, No 4, pp.164-177. ISSN: 1520-5509. Clarion University of Pennsylvania, Clarion, Pennsylvania.

4. Chilunjika, A \& Uwizeyimana, D.E. 2015. Shifts in the Zimbabwean Land Reform Discourse from 1980 to the present. African Journal of Public Affairs, Volume 8, No 3, pp 130-144. Johannesburg, South Africa.

5. Sadomba, Z.W. 2008, War Veterans in Zimbabwe's Land Occupations: Complexities of a liberation movement in an African post-colonial settler society, PhD. Thesis, Wageningen University.

6. Cunningham, C., Cunha, A. P., Brito, S., Marengo, J., \& Coutinho, M. 2017. Climate change and drought in Brazil. In Marchezini, B., Wisner, B., Londe, L.R \& Saito, S.M. (Eds). Reduction of vulnerability to disasters. From knowledge to action. (pp. 361-375). Sao Carlos, Brazil: Editora RiMa. 
7. ERCC (Emergency Response Coordination Centre). 2019. Southern Africa drought situation. DG ECHO Daily Map. Available at https://reliefweb.int/map/zimbabwe/southern-africa-drought-situtationemergency-response-coordination-centre-ercc-dg-echo Accessed on 29 September 2019.

8. Chingono, M \& Adebayo, B. 2019. CNN News. Millions in Zimbabwe facing starvation after severe droughts. Available at https://edition.cnn.com/2019/08/07/africa/zimbabwe-millions-starvationintl/index.html Accessed on 25 September 2019.

9. UNICEF (United Nations International Children's Emergency Fund). 2019. Zimbabwe Humanitarian Situation Report - Multi-Hazard Mid-year SitRep. Pp1-11.

10. Alam, M., Bhatia, R., Clinton, H.R. \& Mawby, B. 2015. Women and climate change: Impact and agency in human rights, security, and economic development. Georgetown Institute for Women, Peace and Security.

11. Engelbrecht, F., Adegoke, J., Bopape, M., Naidoo, M., Garland, R., Thatcher, M., McGregor, J., Katzfey, J., Werner, M., Ichoku, C \& Gatebe, C. 2015. Projections of rapidly rising surface temperatures over Africa under low mitigation. Environmental Research Letters, IOP Publishing Ltd.

12. Coast Adapt, 2017. Global climate change and sea-level rise. Available at https://coastadapt.com.au/globalclimate-change-and-sea-level-rise Accessed on 18 June 2020.

13. IPCC (Intergovernmental Panel on Climate Change). 2018. Special Report on the impacts of global warming of $1.5^{\circ} \mathrm{C}$. Summary for Policymakers. Switzerland.

14. Brown, D., Chanakira, R., Chatiza, K., Dhliwayo, M., Dodman, D., Masiiwa, M., Muchadenyika, D., Prisca Mugabe, P. and Zvigadza, S. 2012. Climate change impacts, vulnerability and adaptation in Zimbabwe. IIED Climate Change Working Paper No. 3.

15. Tanyanyiwa, V.I \& Mufunda E. 2020. Sociocultural impact of climate change on women and the girl child in Domboshawa, Zimbabwe. In: Leal Filho W., Azul A.M., Brandli L., Özuyar P.G., Wall T. (eds) Climate Action. Encyclopedia of the UN Sustainable Development Goals. Springer, Cham. https://doi.org/10.1007/978-3-319-95885-9_118.

16. FAO (Food and Agriculture Organisation). 2018. Realizing women's rights to land in the law A guide for reporting on SDG indicator 5.a.2. ISBN 978-92-5-130401-3.

17. EMA (Environmental Management Agency). 2014. Mashonaland Central province. Zimbabwe.

18. ZIMSTAT (Zimbabwe Statistics). 2012. Zimbabwe National Statistics Agent. Census 2012 National Report.

19. Musemwa, L. 2011. Economics of land reform models used in Mashonaland Central Province of Zimbabwe. Unpublished. PhD Thesis. University of Fort Hare, Alice, South Africa.

20. Zimfact. 2018. Agriculture in Zimbabwe. Available at https://zimfact.org/agriculture_in_zimbabwe/ Accessed on 30 August 2020.

21. Ministry of Lands Agriculture, Water, Climate and Rural resettlement. 2017. Rainfall characteristics in the five natural regions of Zimbabwe. Available at http://www.moa.gov.zw/index.php/zim/25 August 2020.

22. Frankenberg, E., Sikoki, B., Sumantri, C., Suriastini, W \& Thomas, D. 2013. Education, vulnerability, and resilience after a natural disaster. Ecology Society, Jornal for intragrative science for resilience and sustainability, vol 18, No 2, 16. doi: 10.5751/ES-05377-180216.

23. Tau, P. 2015. News24. Drought starts taking its toll on livestock farmers. Available at https://www.news24.com/SouthAfrica/News/drought-starts-taking-its-toll-on-livestock-farmers-20151108 Accessed on 28 November 2019.

24. FAO (Food and Agriculture Organisation). 2019. El Niño response plan for Southern Africa - Zimbabwe. ReliefWeb. Available at https://reliefweb.int/report/zimbabwe/fao-2019-humanitarian-appeal-201819-elni-o-response-plan-southern-africa Accessed on 29 September 2019.

(C) 2020 by the authors; licensee MDPI, Basel, Switzerland. This article is an open access article distributed under the terms and conditions of the Creative Commons by Attribution (CC-BY) license (http://creativecommons.org/licenses/by/4.0/). 